\title{
Unraveling the differences between organic and non-organic Thai rice farmers' environmental views and perceptions of well-being
}

\author{
Alexander Harrow Kaufman * \\ Khon Kaen University
}

Submitted September 25, 2014 / Revised January 21, March 4, April 14, and May 4, 2015 / Accepted

May 4, 2015 / Published online July 17, 2015

Citation: Kaufman, A. H. (2015). Unraveling the differences between organic and non-organic Thai rice

farmers' environmental views and perceptions of well-being. Journal of Agriculture, Food Systems, and

Community Development, 5(4), 29-47. http://dx.doi.org/10.5304/jafscd.2015.054.002

Copyright (C) 2015 by New Leaf Associates, Inc.

\begin{abstract}
Food production, a critical aspect of human development, depends on the regulating and supporting services of the ecosystem. However, the expansion and intensification of agriculture to meet rising human consumption levels have played havoc with ecosystem provisioning services by way of climate change, biodiversity loss, soil degradation, and water pollution. Development experts argue that modern agricultural methods also have led to the exodus of farmers from rural to urban areas and the disintegration of rural social safety nets. Few studies have explored the impacts of a shift to modern agricultural methods on farmers' wellbeing from a holistic perspective. This research sheds light on organic and non-organic farmers' environmental views, well-being, and production

\footnotetext{
* Alexander Harrow Kaufman, MSc, Ph.D., Research Fellow, Research Group on Wellbeing and Sustainable Development; 2405-2406, 4th Floor, Building HS 02; Faculty of Humanities and Social Sciences; Khon Kaen University; 123 Mitraparb Road, Muang District 40002; Khon Kaen Province, Thailand; kaufman.alex@gmail.com
}

methods in the impoverished Northeast Region of Thailand. Structured questionnaires were used to examine differences in farmers' perspectives on their own well-being. Analysis shows that a Buddhist environmental worldview was not exclusive to either organic or non-organic farmers. Organic rice farmers were no more food secure than those farmers who used synthetic agrochemicals to raise productivity. Participants from both groups also suffered from similar levels of stress due to outstanding loans. While some organic farmers sustained high levels of food security and were able to lower debts by using organic fertilizer methods, they also were bound by the financial demands of their families. It is highly recommended that experts consider farmers' environmental views and perceptions of well-being before deciding on ways to attract them to organic agriculture.

\section{Keywords}

organic agriculture, Buddhism, environmental, well-being, world views 


\section{Introduction}

Food production, a critical aspect of human wellbeing, depends on the regulating and supporting services of the ecosystem ${ }^{1}$ through nutrient cycling, primary production, and soil formation (Millennium Ecosystem Assessment [MA], 2005). Over the last century, humankind has greatly expanded the food supply through technological innovations in agriculture: hybrid seeds, synthetic fertilizers, pesticides, herbicides, and fungicides. On the other hand, the expansion and intensification of agriculture to meet rising human consumption levels have played havoc with ecosystem provisioning services (e.g., food, water, fiber, and fuel) by way of climate change, biodiversity loss, and soil degradation (Drinkwater, Letouneau, Workneh, van Bruggen, \& Shennan, 1995; Sandhu, Wratten, \& Cullen, 2010; United Nations Development Program [UNDP], 2007). The excessive use of synthetic fertilizers to raise farm productivity also has degraded water quality and caused a decline in fisheries (McIsaac, David, Gertner, \& Goolsby, 2001). While experts argue that synthetic fertilizers are integral to expanding food production, studies show that organic methods of stimulating soil fertility offer equivalent yields (Pimentel, Hepperly, Hanson, Douds, \& Seidel, 2005). Moreover, researchers have found that farming methods heavily reliant on pesticides cause serious health problems for farmers and their families (Schreinemachers, Schad, Tipraqsa, Williams, Neef, Riwthong, Sangchan \& Grovermann, 2012). Despite greater knowledge of the impacts of high input, intensive agriculture on ecosystem services, the pursuit of increased yields continues to be a dominant factor in the decisionmaking of farmers, governmental agencies, and nonprofit organizations.

Responding to these challenges, alternative agriculturalists have called for a shift to organic agriculture methods (Pretty, 2003). Scholars contend that organic agriculture represents an alternative paradigm of development rooted in renewable inputs, traditional knowledge, communal labor, fresh markets, and localized food networks. Critics

\footnotetext{
1 "An ecosystem is a dynamic complex of plant, animal, and microorganism communities and the nonliving environment interacting as a functional unit. Humans are an integral part of
}

of what has been named "conventional agriculture" contend that the use of intensive agriculture methods has degraded food quality (Allen, 2004; Beus \& Dunlap, 1990). Moreover, the expansion of global food supply chains has dislocated consumers from their "foodsheds" (Feagan, 2007). Jarosz (2000) found that this reconfiguration of the food production system has eroded the "relations of trust" that once existed between farmers and consumers. Further changes associated with "conventional" forms of agricultural development have been blamed for the gradual decay of rural society in both developing and developed economies (Pretty, 2003).

Although scholarship has uncovered some of the societal benefits of alternative agriculture, the composition of food production systems in developing countries differ greatly from the that described in North American and European agrofood literature (Baconguis \& Cruz, 2005; Curry, 2000; Duram, 2000). A major distinction is that Western supermarkets stock large quantities of organic and non-organic crops cultivated in developing countries. Moreover, North American organic farms depend on a largely migrant workforce and have reached an industrial scale (Allen, 2004). In contrast, the Thai organic marketplace is dominated by locally grown crops produced on smallholder farms of less than 12.4 acres (5 hectares) (Panyakul \& Wanlop, 2007). Smallholder farmers also have benefited from a growth in consumer demand for organic products. Then again, certified organic agriculture has only reached one percent of Thailand's arable land (McNeely \& Scherr, 2003; Willer \& Yussefi, 2004). With an aim to increase these numbers, experts have sought to explore the reasons so few Thai farmers have made the shift to organic agriculture (Hutanawat \& Hutanawat, 2006; Samerpak, 2006; Thongtawee, 2006; Kaufman \& Mock, 2014). However, less is known about the ways farmers benefit from a shift to organic agricultural methods. This article explores differences between Thai organic and non-organic rice farmers by asking two principal

ecosystems" (Millennium Ecosystems Assessment [MA], 2005, p. 23). 
questions: Is there a fundamental difference between the environmental views of organic and non-organic farmers? Do farmers who use only organic agricultural methods experience well-being differently than farmers who rely on agrochemicals?

\section{Ecosystems Services and Human Well-being}

To achieve adequate levels of well-being, human society depends upon the integrity of ecosystem services. However, the ways in which people access these services directly affect their culture, food security, health, social relationships, socioeconomic status, and perceptions of well-being. Of further significance, the Millennium Ecosystem Assessment (MA) Conceptual Framework highlights the intangible benefits of a healthy ecosystem to human well-being: "spiritual and religious value, knowledge systems, educational value, inspiration, aesthetic value, social relations, sense of place, cultural heritage and recreation" (MA, 2005, p. vii). Along these lines, decision-makers have shown greater interest in using "subjective" measures of well-being to evaluate the quality of people's lives, particularly in developing countries (Rojas, 2007).

Building on the MA, this research examines the premise of an interrelationship between farmers' perceptions of their wellness and the integrity of their agro-ecosystems. As Paknawin-Mock (2000) explains, "Thais believe that mental, spiritual and bodily well-being are intertwined one with another" (p. 11). In other words, Thais experience health from a holistic perspective, rather than only through an "absence of disease and infirmity" (World Health Organization, 1946, p. 2). Experts have found that a single question designed to evaluate participants' overall wellness is often an accurate indicator of "good" health (Bowling, 2005). Drentea and Lavrakas (2000) revealed that debt bears on health through related increases in stress levels. Researchers also have linked reduced access to culturally appropriate and nutritious foods with a decline in the health of some indigenous people (Kuhnlein et al., 2006). In addition, as many farmer households no longer cultivate a diversity of food products, their ability to meet their dietary demands hinges upon the prices they attain for their goods in the marketplace (Sen, 1986).

\section{The Development of Organic Agriculture in Thailand} During the latter part of the $20^{\text {th }}$ century, development policies pursued by the Thai government resulted in widespread environmental degradation. A combined increase in dam projects, logging concessions, and commercial farming led to unprecedented levels of deforestation. To expand forest cover, the government established a number of national parks and reserves throughout the Thai state (Hardwick, Healey, Elliott, \& Blakesley, 2004). In the process, forests became more secure. However, communities along the periphery of these reserves were prevented from access to wild foods, barter, and places of spiritual value. While social activists fought for the rights of villagers to the forest, others sought to prevent encroachment, on the grounds that nature has an intrinsic value (Darlington, 2012).

In the 1980s, local civil society organizations (CSOs) began to invoke specific Buddhist scriptures with the intent of fostering an environmental consciousness in the rural population. In doing so environmental and social activists were constructing an environmental ethic upon the teachings of the Four Noble Truths (related to the reduction of dukkba or suffering). According to Kabilsingh (2010), practicing Buddhists have an obligation to diminish dukkha by radiating loving-kindness towards both sentient and insentient beings. Henning (2002) further explains, "Buddhist teachings recognize that all living things are interdependent and conditional upon each other" (p. 12).

As a means to translate these abstract teachings into concrete actions, some Thai Buddhist monks took it upon themselves to ordain trees by wrapping them with saffron robes. However, this spiritual defense from the chainsaws of villagers and logging companies led to increased tensions over land rights. As a result of these actions, some prominent forest monks were arrested, intimidated, and even murdered by purportedly "influential people" (Darlington, 2012). In spite of the good intentions of these monks, a number of Buddhist scholars have questioned the legitimacy of using 
ceremonies reserved for humankind in the name of the forest (Falvey, 2000).

In the 1980s, a growing awareness of the environmental and health impacts of using synthetic agro-chemicals convinced some farmers to adopt alternative agriculture methods. Inspired by the sermons of the late Buddhahassa Bhikku (former abbot of the Suan Mokh Temple, Surathani Province, Southern Thailand), CSOs funded programs aimed at restoring dignity to the profession of farming (Bhikkhu, 1991/2002) and forestalling environmental degradation through Buddhakaset (Buddhist agriculture) (Bhikkhu, 1991/2002). Social activists worked with alternative agriculture leaders to ensure they were developing courses for farmers that emphasized the value of a Thai traditional way of life informed by Buddhist values (Wasi, 1988).

The Santi Asoke (SA) religious sect called upon these interpretations of the Buddhist scriptures as a road map for development. Led by the former monk Samana Bodhirak, ${ }^{2}$ SA was one of the first to take on Buddhakaset at a community level. To bring their concept of a Buddhist utopia to fruition, a strict dogma was enacted based on principles of morality, reduced consumption and hard work (Essen, 2005). Members also took a vow to follow the Five Precepts: (1) not to kill any living being; (2) not to take what is not freely given by the owner (stealing); (3) not to indulge in sexual misconduct; (4) not to lie; and (5) not to consume intoxicants. To abide by the First Precept, followers elected to use only natural agriculture methods (Henning, 2002; Payutto, 1998). They also manufactured their own organic food products and adhered to a strict vegan diet. In this way, SA members succeeded in both raising their level of self-sufficiency and warding off the influences of an increasingly materialist society (at least within the walls of their communes). Bodhirak and his followers established nine long-standing Buddhist

2 In 1992, Samana Bodhirak was defrocked by the Central Buddhist Order in Bangkok for breaching monastic precepts. 3 According to the Guidance Document for Compliance with Organic Agriculture Certification Thailand (ACT): (1) Synthetic fertilizers are prohibited; (2) Insecticides and herbicides are prohibited; (3) Synthetic hormones are prohibited; (4) Farm equipment used for conventional communes with funding from private donations, vegan restaurants, and cooperatives stores

(Kaewthep, 2008).

Although alternative agriculture CSOs have invoked abstract Buddhist scriptures to advocate for agriculture methods that cause minimal harm to nature, experts also have developed a number of scientific techniques used by organic and nonorganic farmers alike. Setboonsarng and Gilman (1999) note the popularity of Thai versions of the Japanese biofertilizer Effective Microorganisms (EM). Many CSOs have taught farmers how to make EM by mixing a combination of food scraps, beneficial microbes, and molasses and fermenting them in water. In addition, the secular Bangkokbased Green Net Cooperative/Earth Net Foundation has provided training on organic certification requirements ${ }^{3}$ as well as entered into purchasing agreements with member farmers (International Federation of Organic Agricultural Movements [IFOAM], n.d.; Samerpak, 2006). Trainers from diverse organizations have emphasized the importance of growing and consuming organic products as a preventive health measure. Increasingly, courses have included modules on detoxification and the use of traditional Thai herbal medicines (Kaufman \& Mock, 2014).

In the 1990s, the interests of alternative agriculture CSOs began to merge with various programs under financial support from the Thai Royal family, in particular the Sufficiency Economy (SE) philosophy. Formulated by the king of Thailand, Bhumipol Adulyedej, SE is a flexible set of guidelines aimed at encouraging the public to moderate consumption patterns, sustain reasonable levels of development and provide immunity from fluctuations in external markets (Chantalakhana \& Falvey, 2008). To promote SE, CSOs and government organizations have developed training courses around the concept of a three-stage process: building integrated farms (also referred to

farming shall not be used for organic farming; (5) The farmer must maintain records of sources of all farm inputs; (6) Crops in organic fields must be separate from crops in conventional fields; (7) Organic crops must be at a minimum 3.3 feet ( 1 meter) away from conventional crops. Note: ACT guidelines have been abbreviated for use in this paper. 
as New Theory Agriculture), raising communitylevel integrity and setting up supportive regional networks (Sathirathai \& Piboolsravut, 2004). Under the government's Ninth National Social and Economic Development Plan (2002-2006), SE philosophy was formally integrated into a set of policy directives aimed at sustainable agricultural development: integrated farming systems, organic farming, natural farming and agro-forestry (Thongtawee, 2006). Government agencies worked closely with alternative agriculture CSOs to deliver $\mathrm{SE}$ training programs to farmers nationwide.

In spite of the value of external support, the availability of family-based labor and access to key resources are critical to sustaining organic agriculture in Thailand (Kiatsuphimol, 2002). Researchers found that in the northeastern Thai province of Yasothon, organic farmers who built up smallscale, village-based collectives were better equipped to sustain organic rice production. These smallscale collectives provided access to fertilizer components, machinery, and rice-milling machines (Hutanawat \& Hutanawat, 2006). The benefits participants accrued played a part in increased levels of social capital among members (Putnam, 2008). Importantly, these social connections provided a basis for sharing information about organic agriculture (Kaufman, 2012). Thongtawee (2006) reported that Thai organic farmers used the term kalyanamitta ("virtuous friends" in Pali, the language of Theravada Buddhism) to describe the benefits of working together. Recent research shows a correlation between membership in organic fertilizer collectives and a reduction in debt among members of the Dharma Garden (Buddhist) Temple in Yasothon Province (Kaufman \& Mock, 2014). While these studies suggest that membership in organic agriculture collectives offers multiple benefits, critics claim that these systems are less profitable due to the additional labor demands required of individual farmers (Becchetti, Conzo \& Gianfreda, 2012). Although the aforementioned arguments are noteworthy, few studies have exhibited the nonfinancial benefits of a shift to organic agriculture through quantitative research methods. Notwithstanding, this research also examines financial status as one of several components that determine Thai farmers' perceptions of their well-being.

\section{Scope of the Study}

Fearing that rapid population growth in Asia would overtake food production levels, policy-makers sought ways to raise the food supply. Researchers at the International Rice Research Institute in the Philippines assisted by developing new breeds of rice that grew faster, produced more edible flesh than traditional varieties, and were resistant to specific predator species (White, 1994). Rice production levels were improved through an increase in synthetic fertilizers and a steady water supply. Later, pesticides, herbicides, and machinery were introduced to manage pest problems and reduce labor requirements. To exploit this so-called Green Revolution technology, the Thai government enacted a series of policy changes to assist farmers (Shiva, 1991; UNDP, 1994). The first measure was "security of land title," which enabled farmers to use their land as collateral for agricultural loans (Panyakul \& Wanlop, 2007). A national system of cooperatives was instituted to provide farmers with improved access to agro-chemicals and market access. These initiatives were solidified in the 1960s by the national government's decision to set up a cooperative banking system, later renamed the Bank of Agriculture and Agricultural Cooperatives, or BAAC (Ratanamalai, 1998). Whereas access to capital helped cooperative members negotiate lower purchase prices, most of the funds were used to purchase synthetic fertilizers (Preedasak \& NaRanong, 1998).

Significantly, the expansion of these government supported credit systems enabled farmers in Thailand's Central Region to raise production levels. However, farmers in the Northeast Region (Issan) (Figure 1) have been hindered by poor soil quality, infrequent rainfall, and a lack of access to irrigated water (Grandstaff, Grandstaff, Limpinuntana, \& Suphanchaimat, 2008). Further data show that Issan farmers have suffered from high debt levels and lower wages than their counterparts in the Central Region (National Statistics Office, 2011). To raise earnings, Issan farmers have shifted from seasonal production 
Figure 1. Ubon Ratchathani, Northeast Region of Thailand

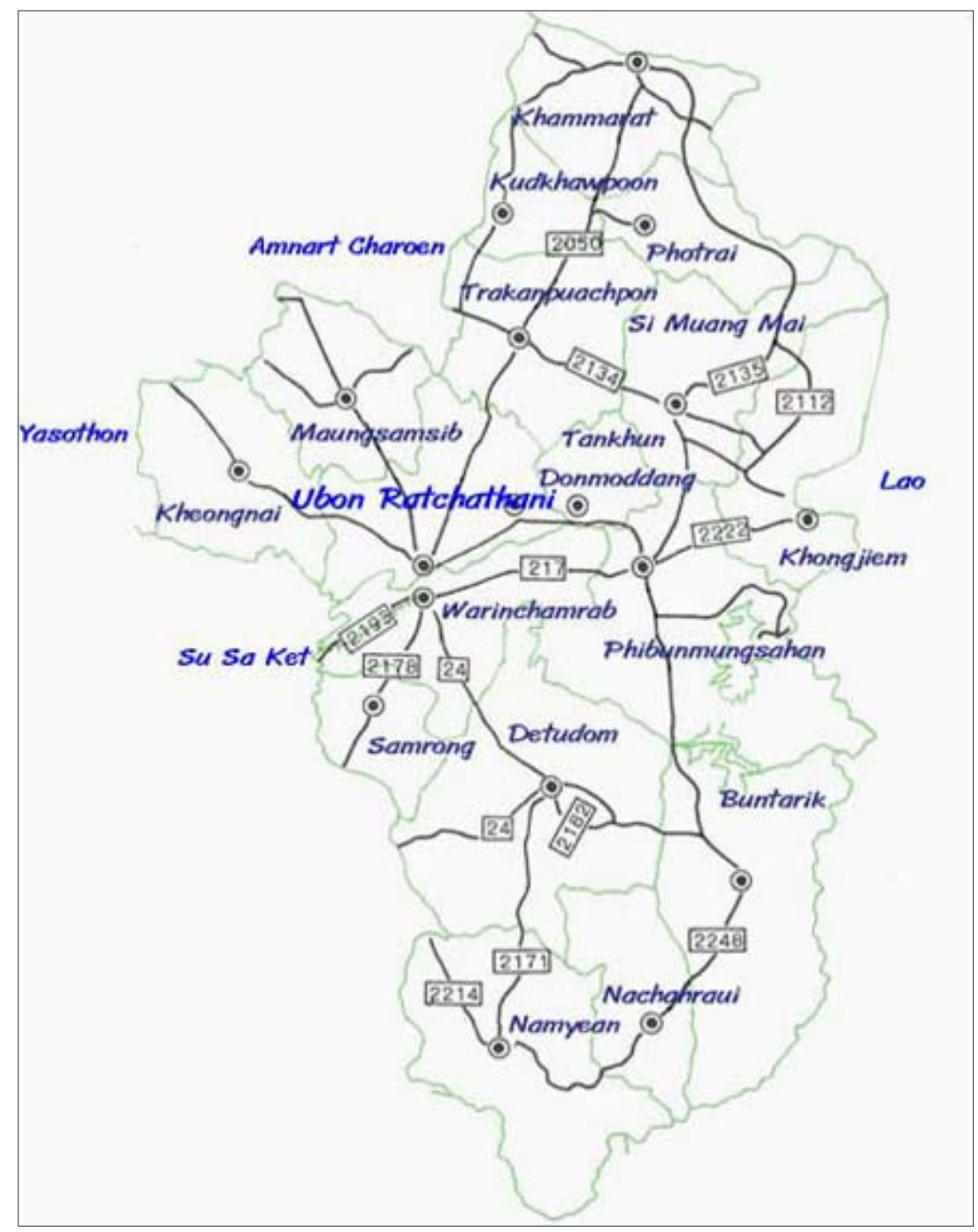

attempts to raise household income levels (National Statistics Office, 2011; Rigg, 1997).

Although Theravada Buddhism ${ }^{4}$ forms an integral part of the social structure of Issan rural life, many people also pay reverence to Mae Thoranee (Earth Mother), Mae Khongka (River Mother), Mae Phosop (Rice Mother), and Khwan Khao (Rice soul) (Sirisai, 1990). However, as part of the centralization of government authority in the early 1900s, many of these animist beliefs were brought under the auspices of the Thai Sangha (Buddhist administration based in Bangkok). One critical aspect of the resulting changes was the incorporation of animist rituals into what the Thai government called the Heed Sipsong (twelve customs): "offering food to ancestors and guardians; receiving great sermons; showering festival; praying for rain; offering food and respect to house and community; Buddhist lent; offering food and making merit to ancestors; offering food and paying respect to paddy guardians; completion of

schedules to multiple cropping systems. To afford mechanical innovations, such as the kway lhek (iron buffalo, a Kubota brand hand-held tractor), farmers have taken temporary jobs in Bangkok (Falvey, 2000; Funahasi, 1996). The concomitant shortage of village-based labor has led to the virtual disappearance of nonmonetary labor exchange (Tanabe, 1994). While these problems are endemic to much of Thailand, the socio-economic and environmental challenges of raising agricultural productivity in Issan have continued to obstruct

${ }^{4}$ Theravada Buddhism, or the "Teaching of the Elders," is said to have migrated from Ceylon (Sri Lanka) and to have taken hold on the Siam (Thai) Peninsula between the sixth and lent; making grand merit; praying for forgiveness" (Panya, 1995, p. 163). As part of their duties, rural government officers worked to make these new customs a part of community life. From a development perspective, the imposition of the Heed Sipsong helped set the stage for a shift from a village-based to a planned economy (Panya, 1995). This article examines the lives of rice farmers in Ubon Ratchathani, one of 19 provinces in Issan. Similar to most Issan people, the inhabitants of Ubon Ratchathani are primarily of the Laotian

ninth centuries. The Noble Truths, the Eightfold Path, the Dependent Origination, and the law of Karma are the key principles of Theravada Buddhism (Payutto, 2001). 
ethnic group. Although most speak Thai (the official language), the Issan language (a dialect of Lao) is widely used by rural dwellers and government officials. Ubon Ratchathani is historically significant, having served as the seat of administration for the Northeast Region during the reign of King Chulalongkorn (1868-1910) (Wyatt, 1982). Ubon Ratchathani is also a major trading center, bordering Laos to the east and Cambodia to the south. Despite its strategic location, agriculture is still a principal form of employment. As in most parts of Issan, Ubon farmers grow jasmine rice for sale and glutinous (sticky) rice primarily for home consumption. Issan farmers supplement dietary requirements by gathering food in community forests and fish, frogs, and wild vegetables from their rice paddies. In the rainy season, these naturally occurring food sources may make up to half of their dietary requirements (Lovelace, Subhadhira \& Simarks, 1998). In the last few decades Issan farmers have shifted away from subsistence rice farming to cultivate a variety of cash crops, such as cassava, corn, sugar cane, eucalyptus, and rubber trees (Falvey, 2000).

\section{Methods}

Pondering the ways in which people in rural and urban areas relate to the natural environment, Western researchers have increasingly turned to mixed methods (Duram, 2000; Modell, 2009; Sullivan, McCann, De Young, \& Erickson, 1996). Beus and Dunlap (1990) used qualitative methods to explore differences between two "competing paradigms" of agricultural development. Kempton, Boster, and Hartley (1997) used structured questionnaires to show that environmental decisionmaking in North America was based on "cultural models," or the beliefs and values shared by a community or society. The architects of the "New Environmental Paradigm" employed statistical models to measure human "beliefs concerning their relationship to the natural world" (Mayer \& Frantz, 2004, p. 505). Although the tools they employed provided a useful framework for designing this research, the aforementioned studies speak to people in developed economies whose values are largely influenced by a "built environment" and formal education systems (Franklin, 2002).

\section{Sampling and Data}

Due to the challenges of independently gaining access to farmers in rural areas of Northeast Thailand, I requested assistance from the BAAC provincial office in Ubon Ratchathani in the recruitment of participants. The BAAC provided a list of 247 farmers that had enrolled in the Sufficiency Economy (SE) Philosophy Community Pilot Project in 2012. This BAAC-sponsored training program aimed to teach participants ways to raise their level of self-reliance by reducing household expenses. Participants also learned how to account for monthly expenses, make organic fertilizers, grow vegetables for household consumption, work in groups, and retain local knowledge of farming practices.

An exhaustive review of the participant list revealed that roughly half of the organic farmers used organic methods on only a small portion of their landholdings (less than 2.5 acres or 1 hectare). Moreover, many participants reported that they had given up cultivating these so-called "experimental" plots a few years after the initial BAAC trainings. As such, a purposive sampling method was decided upon to choose organic and nonorganic farmers for this research. The total sample of 139 (75 organic and 64 non-organic) farmers who participated in this study were located in seven districts of Ubon Ratchathani Province: Trakan Phutphon, Det Udom, Samrong, Khuan Nai, Muang Samsip, and Tan Sum. The distribution of the sample was based on the number of participants who presented themselves for interviews at the dates and locations set by the BAAC. Interviews were conducted around participants' farms, collectives, and meeting areas, and at BAAC district offices.

A structured questionnaire was designed to elicit information about participants' households, environmental views, perception of well-being, and production methods. Well-being was examined in terms of participants' ability to achieve "good" health and fulfill dietary requirements, material needs, and social and family aspirations (MA, 2005; Rojas, 2007). Queries were formulated based on 
Northeastern Thai beliefs, customs, and farming practices, and as well as teachings disseminated by Thai alternative agriculture CSOs (Author name(s) removed, 2012; Essen, 2005; Hutanawat \& Hutanawat, 2006; Thongtawee, 2006). The construction of questions and responses were adopted from previous research on farmers in North America and Thailand (Kaufman, 2012; National Institute of Health, 2006).

Demographic data, items with responses measured on a Likert scale, and multiple-choice items from the questionnaires were analyzed by generating descriptive statistics with Statistical Package for Social Sciences (SPSS v.18) computer software. As a method to provide greater congruence between responses, these variables were transformed (recoded in a consistent direction). The variables selected for use in this article were chosen based on congruence, relevance, and a positive association through preliminary analyses using Pearson's correlations (see Table 1).

Cross tabulations were used to interpret demographic variations between organic and nonorganic farmers. One-way ANOVAs were used to compare mean differences on measures for the two groups (organic and non-organic farmers). $F$ tests of significance were used to determine whether the $F$ values were significant at a $5 \%$ level $(\phi<0.05)$.

\section{Table 1. Key Categories, Related Questions, and Responses}

\begin{tabular}{|c|c|c|}
\hline Subject & Variables & Scales \\
\hline Environmental Views & $\begin{array}{l}\text { (a) First Precept means "not to kill living things } \\
\text { on the farm" } \\
\text { (b) Farmers have a duty to protect the } \\
\text { environment on their farms } \\
\text { (c) Agro-chemicals damage the natural } \\
\text { environment } \\
\text { (d) Agro-chemicals produce harmful food for } \\
\text { consumers }\end{array}$ & $\begin{array}{l}\text { (a) and(b) high score=high level of agreement } \\
\text { with a Buddhist environmental ethic }(1-5) \\
\text { (c) and (d) high scores=pro-environmental } \\
\text { worldview (1-5) }\end{array}$ \\
\hline Health Views & $\begin{array}{l}\text { (a) Sad, angry, depressed due to financial } \\
\text { situation } \\
\text { (b) Physical pain interrupted farm work in last } 3 \\
\text { months } \\
\text { (c) Stamina compared with other farmers your } \\
\text { age } \\
\text { (d) Describe your current health status }\end{array}$ & $\begin{array}{l}\text { (a) high score=low incidence of feeling sad } \\
\text { and/or angry (1-4) } \\
\text { (b) high score=low incidence of pain (1-4) } \\
\text { (c) high score=high level of stamina (1-4) } \\
\text { (d) high score=high level of health }(1-5)\end{array}$ \\
\hline Financial Views & $\begin{array}{l}\text { (a) Non-agricultural income } \\
\text { (b) Loan status over last } 5 \text { years } \\
\text { (c) Income trend over the last } 5 \text { years }\end{array}$ & $\begin{array}{l}\text { (a) dichotomous variables }(0,1), 0=\text { no, } 1=y e s \\
\text { (b) high score=low level of loans }(1-6) \\
\text { (c) high score=high level of income stability } \\
(1-5)\end{array}$ \\
\hline Social Relations & $\begin{array}{l}\text { (a) Member of a fertilizer collective } \\
\text { (b) Good friends in collective } \\
\text { (c) Expert knowledge of organic in collective } \\
\text { (d) Do you exchange labor in collective } \\
\text { (e) Exchange of labor for how many tasks }\end{array}$ & $\begin{array}{l}\text { (a) and (d) dichotomous variables }(0,1), 0=\text { no, } \\
1=y e s \\
\text { (b) high score=high level of social relations } \\
(0-2) \\
\text { (c) high score=high level of knowledge }(1-4) \\
\text { (e) high score=high number of tasks }(0-2)\end{array}$ \\
\hline Production Methods & $\begin{array}{l}\text { (a) Use of effective microorganisms } \\
\text { (b) Use of wood vinegar } \\
\text { (c) Use of green manure } \\
\text { (d) Use of manure }\end{array}$ & dichotomous variables $(0,1), 0=$ no, $1=y e s$ \\
\hline Food Security & $\begin{array}{l}\text { (a) Diversity of household food from your farm } \\
\text { (b) Lacking sufficient food for household (times } \\
\text { per month) } \\
\text { (c) Percentage of household food provided by } \\
\text { naturally occurring sources on your farm }\end{array}$ & $\begin{array}{l}\text { (a) high score=high diversity of farm-based food } \\
\text { access }(1-5) \\
\text { (b) high score=infrequency of days lacking } \\
\text { sufficient food (1-5) } \\
\text { (c) high score=high percentage of food from } \\
\text { natural sources }(1-5)\end{array}$ \\
\hline
\end{tabular}




\section{Results and Discussion}

\section{Demographic Differences Between Organic and}

Non-Organic Farmers

The farmers who participated in this research used both organic and non-organic methods to stimulate the productivity of their rice fields. Of a total sample of 139 farmers, 54\% were classified as organic farmers based on the non-use of synthetic agro-chemicals (i.e., synthetic fertilizers, pesticides, herbicides, and fungicides). The non-organic farmers group ( $46 \%$ of the sample) was composed of those who employed one or more agro-chemicals. While 75 participants reported using exclusively organic agriculture methods, only 19 exhibited the capacity and knowledge to follow organic certification requirements.

In terms of gender differences (Table 2), there was a slightly higher percentage $(45 \%)$ of female organic farmers compared with nonorganic farmers $(39 \%)$. While organic farmers supported more children, non-organic farmers had more adults in their households. This data suggest that the elder children of non-organic farmers have gained employment or pursued educational opportunities outside of their community. More than half $(60 \%)$ of organic farmers had not studied beyond primary scx `x ‘hool, which suggests that a higher level of education completed was not directly related to a decision to adopt organic methods. While the BAAC promoted the diversification of landholdings, a similar percentage of farmers from both groups cultivated
Table 2. Demographic Differences Between Organic and

\section{Non-Organic Farmers}

\begin{tabular}{|c|c|c|c|c|}
\hline \multirow[b]{2}{*}{ Variables } & \multicolumn{2}{|c|}{ Organic $(n=75)$} & \multicolumn{2}{|c|}{ Non-Organic $(n=65)$} \\
\hline & \# & $(\%)$ & \# & $(\%)$ \\
\hline \multicolumn{5}{|l|}{ Gender } \\
\hline Male & 41 & 54.7 & 39 & 60.9 \\
\hline Female & 34 & 45.3 & 25 & 39.1 \\
\hline \multicolumn{5}{|l|}{ Marital Status } \\
\hline Single & 2 & 2.7 & 0 & 0 \\
\hline Married & 63 & 84.0 & 61 & 95.3 \\
\hline Separate, divorced, or widowed & 10 & 13.3 & 3 & 4.7 \\
\hline \multicolumn{5}{|l|}{ Age } \\
\hline 18 to 40 & 13 & 17.3 & 9 & 14.1 \\
\hline 41 or older & 62 & 82.7 & 55 & 85.9 \\
\hline \multicolumn{5}{|l|}{ Education level } \\
\hline 6 th grade or less & 38 & 50.7 & 25 & 39.1 \\
\hline 7th grade and higher & 37 & 49.3 & 39 & 60.9 \\
\hline \multicolumn{5}{|l|}{ Number of children in household } \\
\hline 2 or less & 56 & 74.7 & 52 & 81.2 \\
\hline More than 3 & 19 & 25.3 & 12 & 18.8 \\
\hline \multicolumn{5}{|l|}{ Number of adults in household } \\
\hline 2 or fewer & 34 & 45.3 & 25 & 39.1 \\
\hline More than 3 & 41 & 54.7 & 39 & 60.9 \\
\hline \multicolumn{5}{|l|}{ Other variables } \\
\hline Cultivate vegetables & 21 & 28.0 & 23 & 35.9 \\
\hline Cultivate rubber & 17 & 22.7 & 18 & 28.1 \\
\hline Cultivate cassava & 15 & 20.0 & 16 & 25.0 \\
\hline Animal husbandrya & 43 & 57.3 & 35 & 54.7 \\
\hline Access to irrigation & 33 & 44.0 & 24 & 37.5 \\
\hline Rent portion of farmland & 56 & 74.7 & 53 & 82.8 \\
\hline Part-, full-time, or temporary work off-farm & 38 & 50.7 & 36 & 56.2 \\
\hline Children send support funds & 14 & 18.7 & 13 & 20.3 \\
\hline
\end{tabular}

a Participants primarily raised pigs, chickens, ducks, cows, and buffaloes. vegetables and cash crops (cassava and rubber). Notwithstanding, a greater percentage $(57 \%)$ of organic farmers engaged in animal husbandry, which indicates they had access to fresh manure and an additional source of income. Despite the use of an artificial water supply by non-organic farmers to cultivate a second rice crop, a higher percentage $(44 \%)$ of organic farmers reported having access to irrigated water. A substantial share (more than two-thirds) of participants from both groups rented additional farmland to earn a living. These data indicate that farmers owned insufficient 
landholdings to support their families. Findings also show that farmers from both groups were dependent on income from additional work off their farms. Moreover, a roughly equal percentage of participants relied on remittances from their children working outside their community. Generally speaking, there were only minor variations in the demographic information reported by organic and non-organic farmers.

\section{The Environmental Worldviews of Organic and Non-Organic Farmers}

Organic and non-organic farmers were asked about their environmental views to examine if there was a relationship with the methods they selected to raise the fertility of their rice paddies. Participants' environmental views were judged on their level of agreement with the following phrases on a fivepoint scale: (1) Five Precepts means not to kill living things on the farm; (2) Farmer's duty is to protect the environment on the farm; (3) Agrochemical farming damages the environment; (4) Agro-chemical farming produces food harmful to consumers. See Table 3 for results.

Despite the use of the First Precept "not to kill" by Thai alternative agriculture groups to

Table 3. Differences Between the Environmental Views of Organic and Non-Organic Farmers

\begin{tabular}{lccc}
\hline & $\begin{array}{c}\text { Organic } \\
\text { Farmer } \\
(n=75)\end{array}$ & $\begin{array}{c}\text { Non-Organic } \\
\text { Farmer } \\
(n=64)\end{array}$ & $\begin{array}{c}\text { Statistic/ } \\
\text { Significance }\end{array}$ \\
\hline $\begin{array}{l}\text { Five Precepts means "not to kill living things } \\
\text { on the farm" }\end{array}$ & 3.58 & 3.78 & $F=1.05$ \\
Mean & 1.16 & 1.06 & n.s. ${ }^{{ }^{2}}$ \\
SD & & & \\
\hline Farmer's duty is to protect the environment & 4.62 & 4.56 & $F=0.161$ \\
Mean & 0.91 & 0.97 & n.s. \\
SD & & & \\
\hline Agro-chemical farming damages the & & & \\
environment & 4.17 & 4.58 & $F=5.02$ \\
Mean & 1.16 & 0.92 & $\mathrm{p}<0.05$ \\
SD & & & \\
\hline Agro-chemical farming produces food & & & \\
harmful to consumers & 4.32 & 4.57 & $F=2.07$ \\
Mean & 1.06 & 1.03 & n.s. \\
\hline SD & & & \\
\hline
\end{tabular}

a Abbreviation: $n$.s. $=$ not significant promote organic agriculture methods, organic farmers showed lower means (3.58) than nonorganic farmers (row 1). Organic and non-organic farmers also displayed a similar mean on the item a "farmer's duty is to protect the environment." Markedly, organic farmers exhibited a significantly $(p<0.05)$ lower mean on responses to the statement "agro-chemical farming damages the environment." These findings indicate that the organic farmers in this sample did not select organic agriculture methods out of an interest in protecting the natural environment. Furthermore, non-organic farmers also displayed a higher mean score (4.57) on the item "agro-chemical farming produces food harmful to consumers" (row 4). In contrast with Hutanawat and Hutanawat's (2006) research, this data suggest that non-organic farmers were more aware of the negative impacts of synthetic agrochemical use than organic farmers. However, the reasons non-organic farmers failed to act on this knowledge are inconclusive.

\section{Health Views}

Although this study employed the concept of selfreported health, a medical study of 606 farmers in Northeast Thailand revealed that more than half of its participants displayed "signs and symptoms of pesticide poisoning" (IPM DANIDA, 2004, p. 3). And while experts found that better knowledge of health status has encouraged some farmers to use organic methods, non-organic respondents also were well aware of the health risks associated with agro-chemical use (Thongtawee, 2006). Participants also displayed a similar mean score on queries related to their perceived health status, as displayed in the first section of Table 4 .

While Drentea and Lavrakas (2000) have linked the incidence of debt with increased stress levels, 
findings imply that nonorganic farmers in Ubon Ratchathani were generally happier than organic farmers. Nonetheless, ANOVAs show a significant difference $(p<0.05)$ in means between organic and non-organic farmers related to their perceived feelings of sadness, anger, or depression over debt levels (row 2). It is noteworthy that non-organic farmers displayed a higher mean score (3.47), suggesting that they had a more positive attitude about their financial status. Non-organic farmers also reported experiencing a lower frequency of physical pain over the last 3 months, as displayed by a higher mean score (3.47). This finding suggests that due to the high labor inputs required to sustain organic agriculture, the organic farmers in this study suffered from added physical stress.

Whereas this study relied on participants' ability to report on their own health, results indicate there were no significant differences between organic and non-organic farmers' health status.

Despite the limitations of this questionnaire, single questions about health status were deemed sufficient to measure health as part of participants' overall perception of their wellbeing (Bowling, 2005). As few studies have examined the relationship between health and financial status, it was important to examine specific variables that influenced farmers' perspective of their financial status (Kaufman \& Mock, 2014).

\section{Financial Views}

Although the participants in this study were primarily farmers, they engaged in diverse forms of
Table 5. Differences in the Range of Income from Agriculture Between Organic and Non-Organic Farmers (2013)

\begin{tabular}{lrrrr}
\hline & \multicolumn{2}{c}{ Organic Farmer } \\
& \multicolumn{2}{c}{ a } & \multicolumn{2}{c}{$\begin{array}{c}\text { Non-organic Farmer } \\
(n=64)\end{array}$} \\
Thai Baht & $\#$ & $(\%)$ & $\#$ & $(\%)$ \\
\hline $0-40,000$ & 17 & 22.7 & 12 & 18.8 \\
$41,000-60,000$ & 9 & 12.0 & 10 & 15.6 \\
$61,000-100,000$ & 21 & 28.0 & 11 & 17.2 \\
$101,000-200,000$ & 16 & 21.3 & 12 & 16.0 \\
201,000 or more & 12 & 16.0 & 16 & 25.0 \\
\hline
\end{tabular}

a Average agricultural income: 136,320 Baht.

${ }^{b}$ Average agricultural income: 139,338 Baht. 
derived from non-agricultural work. Similar to the findings of Becchetti, Conzo, and Gianfreda (2012), these results suggest that due to higher labor inputs, organic farmers were less likely to engage in outside sources of employment. Despite the purported labor demands of engaging in organic agriculture, there was little difference in participants' median non-agricultural income (Table 6).

Table 7 shows that there only were minor variations in participants' perceptions of their financial status. Notably, the majority of participants carried some level of debt, and few participants reported low levels of debt (or carried no loans at all). While organic agriculture programs are designed to reduce farmer debt, organic farmer participants displayed an only slightly higher mean score (3.14) in their "loan status over the last 5 years." This data suggests that farmers were not able to substantially reduce their loans by employing only organic agriculture methods.

Findings also suggest that both groups of farmers made up for a shortfall in agricultural earnings through non-agricultural income (e.g., casual labor on other farms, sewing garments, or employment in the government). As for the previously mentioned demographic differences (Table 2), roughly $20 \%$ of farmers from both groups were dependent on remittances from their children. In spite of a diversity of income sources, organic and non-organic farmers experienced a wide range of financial difficulties. Based on observations and interviews at rural BAAC branches, a large number of clients were lined up waiting to receive a partial payment for rice sold to the government, while others reported they were requesting deferment of their loan payments. BAAC staff explained that these problems were due to a shortfall in the budget
Table 7. Differences Between the Financial Views of Organic and Non-Organic Farmers

\begin{tabular}{lccc}
\hline & $\begin{array}{c}\text { Organic } \\
\text { Farmer } \\
(n=75)\end{array}$ & $\begin{array}{c}\text { Non-Organic } \\
\text { Farmer } \\
(n=64)\end{array}$ & $\begin{array}{c}\text { Statistic/ } \\
\text { Significance }\end{array}$ \\
\hline Loan status over the last 5 years & 3.14 & 3.12 & $F=0.008$ \\
Mean & 1.45 & 1.44 & n.s. $^{\text {a }}$ \\
SD & & & \\
Income stability over the last 5 year & 3.48 & 3.73 & $F=2.02$ \\
Mean & 1.10 & 0.98 & n.s. \\
SD & & & \\
Non-agricultural Income & 0.69 & 0.73 & $F=0.280$ \\
Mean & 0.46 & 0.45 & n.s. \\
SD & & &
\end{tabular}

a Abbreviation: n.s.=not significant allocated by the government for its "rice pledging" scheme (2013-2014). Participants reported they had been attracted to the rice pledging scheme with high farm-gate prices. Furthermore, BAAC officers explained that the prices offered to farmers under the rice pledging scheme were higher than premium prices offered by CSOs for organic certified rice. While organic and non-organic farmers grappled with fluctuations in the rice market, collectives offered another way to improve debt status.

\section{Social Relations}

Several studies on Thai organic farming groups discuss the significance of kalayanamitta (virtuous friends) as a factor in sustaining collectives (Hutanawat \& Hutanawat 2006; Thongtawee, 2006). In order to determine the incidence of kalayanamitta in farmer groups, participants were asked about the level of social relations in their

Table 6. Differences in the Non-Agricultural Income Range between Organic and Non-Organic Farmers (2013)

\begin{tabular}{lrrrr} 
Thai Baht & $\#$ & \multicolumn{1}{c}{ (\%) } & $\#$ & (\%) \\
\hline $0-20,000$ & 47 & 62.7 & 32 & 50.0 \\
$21,000-40000$ & 7 & 9.3 & 8 & 12.5 \\
$41,000-60,000$ & 13 & 17.3 & 6 & 9.4 \\
$61,000-80,000$ & 2 & 2.7 & 3 & 4.7 \\
81,000 or more & 6 & 8.0 & 15 & 23.4 \\
\hline
\end{tabular}

3.4

.

a Median non-agricultural income: 28,544 Baht.

Median non-agricultural income: 45,769 Baht. 
collective. Findings showed that collectives are important as a place to acquire and produce key resources for organic agriculture. In addition, farmers exchange knowledge and engaged socially with fellow organic farmers in collectives. Table 8 shows the fundamental differences between farmers' social relations in this study.

Overall, there only were minor differences in the "Social Relations" among the two groups. And there were moderately significant variations $(p<0.05)$ in scores on "Good Friends in Collective" as analyzed through the use of ANOVAs. As exhibited by a higher mean score (1.68) on this item, organic farmers were more likely to have social support in their collective. This finding concurs with other studies of the social dynamics that emerge in the collectives of organic farmers (e.g., Tisenkopf, Lace \& Mierina, 2008). On the other hand, as shown by a slightly higher mean score (3.43) on "Organic Knowledge from Collective," non-organic farmers reported better access to organic agriculture experts in their collectives. Hence, farmers from both groups experienced similar benefits from working in collectives.

\section{Food Security}

In many countries, rural and urban dwellers lack access to culturally appropriate and sufficient food (Kuhnlein et al., 2006). Findings herein show that despite per capita monthly earnings lower than Bangkok residents (National Statistics Office, 2011), most participants reported
Table 8. Differences in Social Relations Views Between Organic and Non-Organic Farmers

\begin{tabular}{lccc}
\hline & $\begin{array}{c}\text { Organic } \\
\text { Farmer } \\
(n=75)\end{array}$ & $\begin{array}{c}\text { Non-Organic } \\
\text { Farmer } \\
(n=64)\end{array}$ & $\begin{array}{c}\text { Statistic/ } \\
\text { Significance }\end{array}$ \\
\hline Member of fertilizer group & 0.55 & 0.63 & $F=0.864$ \\
Mean & 0.50 & 0.49 & n.s. $^{{ }^{a}}$ \\
SD & & & \\
\hline Good friends in collective (kalayanamitta) & 1.68 & 1.40 & $F=4.68$ \\
Mean & 0.70 & 0.79 & $p<0.05$ \\
SD & & & \\
\hline Organic knowledge from collective & 3.37 & 3.43 & $F=0.192$ \\
Mean & 0.91 & 0.79 & n.s. \\
SD & & & \\
Shared labor & 0.72 & 0.66 & $F=0.650$ \\
Mean & 0.45 & 0.48 & n.s. \\
SD & & & \\
\hline Shared labor by tasks & 0.91 & 0.88 & $F=0.068$ \\
Mean & 0.68 & 0.75 & n.s. \\
\hline SD & & &
\end{tabular}

sufficient access to culturally appropriate foods. Furthermore, there were only minor differences in "Food Security" between the organic and nonorganic farmers in this study (Table 9).

While ANOVAs show no statistically significant differences on indicators of "Food Security," organic farmers displayed a slightly higher means (4.52) on the "diversity of food" cultivated on their farm. In addition, non-organic

Table 9. Differences in Food Security Between Organic and Non-Organic Farmers

\begin{tabular}{lccc}
\hline & $\begin{array}{c}\text { Organic } \\
\text { Farmer } \\
(n=75)\end{array}$ & $\begin{array}{c}\text { Non-Organic } \\
\text { Farmer } \\
(n=64)\end{array}$ & $\begin{array}{c}\text { Statistic/ } \\
\text { Significance }\end{array}$ \\
\hline Diversity of food from farm & 4.52 & 4.35 & $F=0.989$ \\
Mean & 0.81 & 1.08 & n.s. $^{a}$ \\
SD & & & \\
\hline Lack of food (times per month) & 4.81 & 4.76 & $F=0.156$ \\
Mean & 0.75 & 0.66 & n.s. \\
SD & 3.17 & 3.34 & $F=0.281$ \\
Percentage of Food from naturally occurring sources & & \\
Mean & 0.90 & 0.95 & n.s. \\
SD & & &
\end{tabular}

a Abbreviation: n.s. $=$ not significant 
Table 10. Differences in Organic Production Methods ${ }^{a}$

\begin{tabular}{lccc}
\hline & $\begin{array}{c}\text { Organic } \\
\text { Farmer } \\
(n=75)\end{array}$ & $\begin{array}{c}\text { Non-Organic } \\
\text { Farmer } \\
(n=64)\end{array}$ & $\begin{array}{c}\text { Statistic/ } \\
\text { Significance }\end{array}$ \\
\hline Effective Microorganisms & 0.13 & 0.31 & $F=6.77$ \\
Mean & 0.34 & 0.47 & $p<0.01$ \\
SD & & & \\
\hline Wood Vinegar & 0.20 & 0.40 & $F=6.31$ \\
Mean & 0.40 & 0.49 & $p<0.05$ \\
SD & & & \\
\hline Green Manure & 0.81 & 0.77 & $F=0.471$ \\
Mean & 0.39 & 0.43 & n.s. b \\
SD & & & \\
\hline Animal Manure & 0.05 & 0.24 & $F=0.053$ \\
Mean & 0.06 & 0.23 & n.s. \\
SD & & &
\end{tabular}

a Use of Effective Microorganisms (EM), green manure, wood vinegar, and animal manure expressed as dichotomous variables, $(1,2) ; 1=$ no, 2=yes.

b Abbreviation: n.s. $=$ not significant

farmers lacked sufficient food to meet their dietary needs more frequently than organic farmers. This data suggest that the organic farmers in this study had achieved only slightly higher levels of food security. Furthermore, organic farmers showed a lower mean score (3.17) on the item related to "naturally occurring food sources." Lovelace, Subhadhira and Simarks (1998) argue that the use of synthetic pesticides bears on the abundance and quality of natural foods. However, the organic rice farmers in this study experienced lower levels of wild frogs, fish, and vegetables around their farms than their non-organic counterparts. Findings from this study also suggest that both groups found it more important to raise income levels as a way to acquire food than to achieve higher levels of food self-sufficiency on their farms (Sen, 1986). As such, diversification of landholdings translated into expanded cultivation of cash crops rather than an increase in the amount of vegetables (or other food) available for home consumption.

\section{Production Methods}

To uncover the ways farmers worked, participants were asked detailed questions about the methods

${ }^{5}$ Green manure refers to the planting and plowing under of legumes or other cover crops that naturally raise the level of they used to raise productivity in their rice fields. Similar to Tisenkopf, Lace, and Mierina's (2008) study of Dutch cooperatives, Thai farmers built up social capital through the relationships forged to produce organic fertilizer. There was only one collective found in Ubon Ratchathani that produced sufficient organic fertilizer for its members. Notably, only a few of their collective members were not certified organic rice farmers.

Like Bhatta and Doppler's (2011) research in Nepal, many of the participants were "default organic" due to an inability to access synthetic fertilizers. However, in contrast to rural areas of Nepal, synthetic fertilizers are widely available in Thailand through provincial cooperatives (Preedasak \& NaRanong, 1998). Some participants reported that they used organic fertilizers because they lacked the funds to purchase synthetic fertilizers. Roughly half of the non-organic participants used animal manure as a cost reduction measure. Table 10 shows the organic agriculture methods used by both groups of participants in their rice paddies.

Data indicate that the use of organic agriculture methods was not exclusive to either group of participants. This phenomenon suggests that some BAAC extension officers were successful at introducing organic agriculture methods. Based on further discussions with farmers, their decisions to use biofertilizers such as EM and green manure ${ }^{5}$ were dependent upon the availability of labor and seeds. While many Thai CSOs prescribed EM as a fundamental component of organic agriculture programs, organic farmer participants displayed a significantly lower mean on the use of EM $(p<0.01)$ and wood vinegar $(p<0.05)$. This data suggest that non-organic farmers also benefited

nitrogen in the soil. 
from using organic agriculture methods. Although some non-organic farmers reported using bagged organic fertilizers, examination of the labeling on these products indicated they also contained inorganic compounds. Overall findings suggest that non-organic farmers were not opposed to organic methods, but had a greater confidence in synthetic fertilizers as a means of raising productivity. When prompted to further explain the reasons they no longer farmed organically, a few farmers (who had experimented with organic rice plots) told interviewers that they experienced low yields. For some of the participants, the initial investment of 3 years to gain organic certification was too long to wait for a positive result (IFOAM, 2012). Some participants also stated that they used agro-chemicals as they lacked access to organic marketing channels. It is notable that the 19 participants who reported being certified under international organic standards produced their own fertilizer and had gained access to a niche market in Italy.

\section{Conclusions}

Although global economic institutions have gone to great lengths to promote human development, they have done so at the expense of the ecosystem (Daly, 1996). While modern agriculture methods have been essential to expanding the global food supply, many experts are critical of the adverse impacts of these innovations on farmer households (Falvey, 2000; Rigg, 1997; Shiva,1991; UNDP, 1994 ). The present study shows that to some extent a dependence on modern agriculture methods has played a part in a decline in the wellbeing of smallholder farmer households. Despite arguments that organic agriculture holds the potential to raise farmers' well-being, the elimination of agro-chemicals does not guarantee they will improve their financial status (Feenstra, 1997; Pretty, 2003). Therefore, appropriate development means not only sustaining local agro-ecosystems, but also providing a means of inclusion for farmers in the global economy. More precisely, farmers' well-being should be measured in terms of their ability to purchase the latest agricultural technology and fulfill the material needs of their family members.
This research aimed to draw out fundamental differences between organic and non-organic farmers. However, comparisons showed that participants from both groups espoused similar environmental values and perceptions of wellbeing. Despite the importance of delving deeper into farmers' values, environmental views played only a small part in participants' decisions to adopt organic agriculture methods. In other words, a Buddhist environmental ethic had failed to reach a substantial number of the organic farmers in Ubon Ratchathani Province. As such, many participants were "default organic" due to insufficient funds rather than out of a desire to protect the natural environment or produce "safe" food for consumers.

The ways organic and non-organic farmers experienced well-being was examined through a comprehensive analysis of their health, financial status, social relations, and food security levels. Whereas some participants believed that adopting organic agriculture led to an improvement in their health, farmers from both groups suffered from similar levels of stress related to their debt burden. On the other hand, non-organic farmers reported a lower incidence of illness and greater stamina than organic farmers. These anomalies are partially explained by the additional labor requirements required to sustain organic agriculture. Notwithstanding, medical examinations could have disclosed a different perspective of participants' health.

The way participants viewed the benefits of organic agriculture also was related to the availability of labor in their households and collectives. Membership in a collective helped many farmers access additional labor, but there was little variation in the incidence of "shared labor" between organic and non-organic farmers. Notwithstanding, in the one collective accredited to organic agriculture standards, members pooled labor and resources to manufacture sufficient quantities of organic fertilizer. There were, however, no formal mechanisms that supported the barter of food in the collectives of either organic or non-organic farmers. In addition, neither group showed a greater tendency toward building household food security. 
Even though the views and perceptions of participants were not significantly different, this study represents only a small portion of Thai farmers. Admittedly, there also was some bias in the sample as all the participants had attended $\mathrm{BAAC}$ organic agriculture training programs. In spite of the limitations of this research, the findings and tools developed in the course of this study offer a foundation for more in-depth research. More importantly, similarities in the socioeconomic characteristics of Southeast Asian agricultural systems offer fertile territory for comparative studies of well-being.

Increasingly, CSOs and governmental institutions in developing countries have looked to organic agriculture programs as a strategy to alleviate poverty. To ensure that organic support programs do more than absorb already scarce funding, it is important that policy-makers understand the reasons so few farmers are able to sustain organic agriculture. Development assistance should not only focus on conserving local agroecosystems, but also on providing farmer groups with the technology (e.g., harvesters, rice mils, packaging equipment) to reduce costs and engage more directly with the marketplace.

While adopting less capital-intensive agriculture methods has helped some farmers to improve their quality of life, they also have become dependent on governmental loans and subsidies. As a measure to make organic and non-organic farmers more self-reliant, policy-makers should aim to decrease direct financial support, especially personal loans. Instead, funding should be aimed at building the strength of small-scale, communitybased collectives. These collectives should be provided with the know-how and technology to produce organic inputs with local resources. Organic farmers also stand to benefit from access to niche markets. Nonetheless, it is important to recognize that farmers' livelihoods are indelibly linked to the integrity of their agro-ecosystems. Consequently it is highly recommended that CSOs and governmental agencies properly evaluate participants' environmental views and perceptions of well-being before deciding upon the best ways to introduce organic agriculture development programs.

\section{Acknowledgements}

I would like to acknowledge the Research Group on Wellbeing and Sustainable Development (WeSD), Faculty of Social Sciences and Humanities, Khon Kaen University, Thailand, for providing financial support. I am especially grateful to the farmers who took time out of their busy schedules to participate in this study. I also wish to thank my Thai coresearchers for adapting and clarifying research questions. Without the assistance of the officers of the Ubon Ratchathani Bank of Agriculture and Agricultural Cooperatives (BAAC) with logistics and providing access to farmer groups, this research would not have been possible. Finally, I would like express my gratitude to the JAFCSD reviewers for their thoughtful comments and suggestions.

\section{References}

Allen, P. (2004). Together at the table: Sustainability and sustenance in the American agrifood system. University Park, Pennsylvania: Pennsylvania State University Press.

Baconguis, R. T., \& Cruz, F. A. (2005). Paradigmatic outlook of alternative and conventional rice farmers in southern Philippines. The Philippines Scientist, 42, 15-39.

Becchetti, L., Conzo, P., \& Gianfreda, G. (2012). Market access, organic farming and productivity: The effects of Fair Trade affiliation on Thai farmer producer groups. Australian Journal of Agricultural and Resource Economics, 56(1), 117-140. http://dx.doi.org/10.1111/j.1467-8489.2011. 00574.x

Beus, C. E., \& Dunlap, R. E. (1990). Conventional versus organic agriculture: The paradigmatic roots of the debate. Rural Sociology, 55(4), 590-616. http://dx.doi.org/10.1111/j.1549-0831.1990. tb00699.x

Bhatta, G. D., \& Doppler, W. (2011). Smallholder periurban organic farming in Nepal: A comparative analysis of farming systems. Journal of Agriculture, Food Systems, and Community Development, 1(3), 163-180. http://dx.doi.org/10.5304/jafscd.2011.013.002

Bhikkhu, B. (1991, March/2002). AgriDhamma: The duty of professional agriculturalists (L. Falvey, Trans.). Lecture at Suan Mokkhapharam, Chaiya, Surat Thani Province, Thailand. Hackney, South Australia: Institute for International Development. http://www.iid.org/uploads/6/2/0/6/6206024/b uddhadasa.pdf 
Bowling, A. (2005). Just one question: If one question works, why ask several? Journal of Epidemiology and Community Health, 59, 342-345. http://dx.doi.org/10.1136/jech.2004.021204

Chantalakhana, C., \& Falvey, L. (2008). Sufficiency economy: An approach for smallholder agricultural development to enhance peace and stability. Bangkok: Sermmit Printing.

Thousand Oaks, CA: Sage Publications.

Curry, J. M. (2000). Community worldview and rural systems: A study of five communities in Iowa. Annals of the Association of American Geographers, 90(4), 693-712. http://dx.doi.org/10.1111/0004$\underline{5608.00218}$

Daly, H. E. (1996). Beyond growth: The economics of sustainable development. Boston, Massachusetts: Beacon Books.

Darlington, S. (2012). The ordination of a tree: The Thai Buddhist environmental movement. Albany, New York: State University of New York Press.

Drentea, P., \& Lavrakas, P. J. (2000). Over the limit: The association among health, race and debt. Social Science \& Medicine, 50(4), 517-529. http://dx.doi.org/10.1016/S0277-9536(99)00298-1

Drinkwater, L. E., Letouneau, D. K., Workneh., F., van Bruggen, A. H. C., \& Shennan, C. (1995).

Fundamental differences between conventional and organic tomato agroecosystems in California, Ecological Applications, 5(4), 1098-1112. http://dx.doi.org/10.2307/2269357

Duram, L. (2000). Agents' perceptions of structure: How Illinois organic farmers view political, economic, social, and ecological factors. Agriculture and Human Values, 17(1), 35-48. http://dx.doi.org/10.1023/A:1007632810301

Essen, J. (2005). "Right development": The Santi Asoke Buddhist Reform Movement of Thailand. Lanham, Maryland: Lexington Books.

Falvey, L. (2000). Thai agriculture: Golden cradle of millennia. Bangkok: Kasetsart University Press.

Feagan, R. (2007). The place of food: Mapping out the "local" in local food systems. Progress in Human Geography, 31(1), 23-42. http://dx.doi.org/10.1177/0309132507073527

Feenstra, G. W. (1997). Local food systems and sustainable communities, American Journal of Alternative Agriculture, 12(1), 28-36. http://dx.doi.org/10.1017/S0889189300007165
Franklin, A. (2002). Nature and social theory. London: SAGE Publications.

Funahashi, K. (1996). Farming by the older generation: The exodus of young labor in Yasothon Province. Southeast Asian Studies 33(4), 625-639.

Grandstaff, T. B., Grandstaff, S., Limpinuntana, V., \& Suphanchaimat, N. (2008). Rainfed revolution in northeast Thailand. Southeast Asian Studies, 46(3), 289-376.

Hardwick, K., Healey, J. R., Elliott, S., \& Blakesley, D. (2004). Research needs for restoring seasonal tropical forests in Thailand: Accelerated natural regeneration. New Forest, 27(3), 285-302. http://dx.doi.org/10.1023/B:NEFO.0000022228. 08887.d2

Henning, D. H. (2002). A manual for Buddhism and deep ecology. Bangkok: The World Buddhist University.

Hutanawat, N., \& Hutanawat, N. (2006). Kasetagam Yangyun Krabuantat Krabuankan leh Tuachiwat [Sustainable agriculture: Vision process and indicators]. Nonthaburi, Thailand: Kledthai Company.

International Federation of Organic Agricultural Movements [IFOAM]. (n.d.). Definitions. Retrieved March 2012 from http://www.ifoam.bio/en/ organic-landmarks/definition-organic-agriculture

IPM DANIDA. (2004). Pesticides-health surveys: Data of 606 farmers in Thailand (Report No. 62). Bangkok: IPM DANIDA. Retrieved from http://thailand. ipm-info.org/download documents.htm

Jarosz, L. (2000). Understanding agri-food networks as social relations, Agriculture and Human V alues, 17(3), 279-283. http://dx.doi.org/10.1023/A:1007692303118

Kabilsingh, C. (2010). Buddhism and nature conservation. Bangkok: Thai Tibet Center.

Kaufman, A. H. (2012). Organic farmers' connectedness with nature: Exploring Thailand's alternative agriculture network. Worldviews: Global Religions, Culture, and Ecology, 16(2), 154-178. http://dx.doi.org/10.1163/156853512X640851

Kaufman, A. H., \& Mock, J. (2014). Cultivating greater well-being: The benefits Thai organic farmers experience from adopting Buddhist eco-spirituality. Journal of Agricultural and Environmental Ethics, 27(6), 871-893. http://dx.doi.org/10.1007/s10806-014-9500-4 
Kaewthep, K. (2008). An “imagining” community: The case of Sisa Asoke, Si Sa Ket Province. In S. Tanabe (Ed.), Imagining communities in Thailand: Ethnographic approaches (pp. 59-82). Chiang Mai, Thailand: Mekong Press.

Kempton, W., Boster, J. S., \& Hartley, J. A. (1997). Environmental values in American culture, Cambridge, Massachusetts: The MIT Press.

Kiatsuphimol, J. (2002). A strategy for Green Net to promote an organic farming product in Bangkok, Thailand (Unpublished master's thesis). Asian Institute of Management, Manila.

Kuhnlein H., Erasmus, B., Creed-Kanashiro, H., Englberger, L., Okeke, C., Turner, N.,... Bhattacharjee, L. (2006). Indigenous peoples' food systems for health: Finding interventions that work. Public Health Nutrition, 9(8), 1013-1019. http://dx.doi.org/10.1017/PHN2006987

Lovelace, G., Subhadhira, S., \& Simarks, S. (1998). Introduction. In G. Lovelace, S. Subhadhira, \& S. Simarks (Eds.), Rapid Rural Appraisal in northeast Thailand: Case studies (pp. 3-19). Khon Khen, Thailand: KKU-Ford Rural Systems Research Project.

Mayer, F. S., \& Frantz, C. M. (2004). The connectedness to nature scale: A measure of individuals' feeling in community with nature, Journal of Environmental Psychology, 24(4), 503-515. http://dx.doi.org/10.1016/j.jenvp.2004.10.001

McIsaac, G. F., David, M. B., Gertner, G. Z., \& Goolsby, D. A. (2001). Eutrophication: Nitrate flux in the Mississippi River Nature, 414, 166-167. http://www.nature.com/nature/index.html

McNeely, J. A., \& Scherr, S. J. (2003). Ecoagriculture: Strategies to feed the world and save wild biodiversity. Washington, D.C.: Island Press.

Millennium Ecosystem Assessment [MA]. (2005). Ecosystems and human well-being: General synthesis, Washington D.C.: Island Press. Retrieved from http://www.millenniumassessment.org/en/ Synthesis.html

Modell, S. (2009). In defense of triangulation: A critical realist approach to mixed methods research in management accounting. Management Accounting Research, 20(3), 208-221. http://dx.doi.org/10.1016/j.mar.2009.04.001
National Institute of Health. (2006). Agricultural Health Study: Phase III Survey Instrument. Retrieved from http://aghealth.nih.gov/collaboration/qx/phase3. pdf

National Statistics Office Thailand. (2011 December). 2010 Thailand statistical yearbook. Retrieved from http://web.nso.go.th/en/pub/oth/pub_oth.htm

Paknawin-Mock, J. (2000). Thai views of wellness, sabaay, smoking, and Buddhist health promotion (Unpublished doctoral dissertation). University of California, San Francisco, San Francisco.

Panya, O. (1995). Change from within: Adaptation and selfdetermination in three rural communities of northeast Thailand 1900-1992 (Unpublished doctoral dissertation). Victoria University of Wellington, New Zealand.

Panyakul, V., \& Wanlop, P. (2007, December). Country paper: Thailand. Proceedings from the Regional Conference on Organic Agriculture in Asia, Bangkok, Thailand. Retrieved from http://www.intracen.org/Technical-AssistanceProjects-Overview-Regional-Conference-in-Asia/

Payutto, P. A. (1998). A dictionary of Buddhist terms. Bangkok: Mahachulalongkorn University.

Payutto, P. A. (2001). Thai Buddhism in the Buddhist world. Bangkok: Buddhadhamma Foundation.

Pimentel, D., Hepperly, P., Hanson, J., Douds, D., \& Seidel, R. (2005). Environmental, energetic, and economic comparisons of organic and conventional farming systems. BioScience, 55(7), 573-582. http://dx.doi.org/10.1641/0006-3568(2005) 055\%5B0573:EEAECO \%5D2.0.CO;2

Preedasak, P., \& NaRanong, V. (1998, November). Roles of agricultural cooperatives and village credit unions in rural financial markets in Thailand. Session at Decentralized rural development and the role of self help organizations: A regional workshop, offered by the Food and Agriculture Organization Regional Office for Asia and the Pacific Bangkok, Chiang Mai, Thailand. Retrieved from http://www.fao. org/docrep/004/ac158e/ac158e08.htm\#bm08.5

Pretty, J. (2003). Agri-culture: Reconnecting people, land and nature. London: Earthscan Publications.

Putnam, R. (2008). Tuning in, tuning out: The strange disappearance of social capital in America. In T. Donovan \& K. Hoover (Eds.), The elements of social scientific thinking (pp. 145-172). Boston: Thomson Wadsworth. 
Ratanamalai, A. (1998, November). Thailand cooperatives role in decentralized rural development for poverty alleviation and food security at the community level. Session at Decentralized rural development and the role of self help organizations: $A$ regional workshop, offered by the Food and Agriculture Organization Regional Office for Asia and the Pacific Bangkok, Chiang Mai, Thailand. Retrieved from http://www.fao.org/docrep/004/ac158e/ ac158e08.htm\#bm08.2

Rigg, J. (1997). Southeast Asia: the human landscape of modernization and development, London: Routledge.

Rojas, M. (2007). The complexity of wellbeing: A lifesatisfaction conception and a domains-of-life approach. In I. Gough \& J. A. McGregor (Eds.), Wellbeing in developing countries: From theory to research (pp. 259-280). New York: Cambridge University Press.

Samerpak, P. (2006). A strategy for sustainable agriculture system by Rak Thammachat Club in Kudchum District, Yasothon Province, Thailand (Unpublished master's thesis). Manila: Asian Institute of Management.

Sandhu, H. S., Wratten, S. D., \& Cullen, R. (2010). Organic agriculture and ecosystem services. Environmental Science and Policy, 13(1), 1-7. http://dx.doi.org/10.1016/i.envsci.2009.11.002

Sathirathai, S., \& Piboolsravut, P. (2004, November). Sufficiency economy and a bealthy community. Presentation at the $3^{\text {rd }}$ IUCN World Conservation Congress, Bangkok. Retrieved from http://www.sufficiencyeconomy.org

Schreinemachers, P., Schad, I., Tipraqsa P., Williams, P. M., Neef, A., Riwthong, S., ...Grovermann, C. (2012). Can public GAP standards reduce agricultural pesticide use? The case of fruit and vegetable farming in northern Thailand, Agriculture and Human V alues, 29(4), 519-529. http://dx.doi.org/10.1007/s10460-012-9378-6

Sen, A. (1986). Food, economics and entitlements (Working paper 1). Helsinki: United Nations University-World Institute for Development Economics Research.

Setboonsarng, S., \& Gilman, J. (1999). Alternative agriculture in Thailand and Japan. Retrieved from the Horizon International Solutions Site website: http://www.solutions-site.org/node/47
Shiva, V. (1991). The violence of the Green Revolution: Third world agriculture, ecology and politics. Penang: Third World Network.

Sirisai, S. (1990). Rice Goddess and rice farming in Thailand. In T. U. Kyaw \& P. Ratanakul (Eds.), Development, modernization and tradition in southeast Asia (pp. 163-177). Salaya, Thailand: Center of Human Resources Development, Mahidol University.

Sullivan, S., McCann, E., De Young, R., \& Erickson, D. (1996). Farmers' attitudes about farming and the environment: A survey of conventional and organic farmers. Journal of Agriculture and Environmental Ethics, 9(2), 123-143. http://dx.doi.org/10.1007/BF03055298

Tanabe, S. (1994). Ecology and practical technology: Peasant farming systems in Thailand. Bangkok: White Lotus.

Thongtawee, C. (2006). Attractors in paradigm shift process towards sustainable agriculture of farmers (Unpublished doctoral dissertation). Mahidol University, Nakhon Pathom, Thailand.

Tisenkopf, T., Lace, I., \& Mierina, I. (2008). Social capital. In J. D. van der Ploeg \& T. Marsden (Eds.), Unfolding webs: The dynamics of regional rural development (pp. 87-110). Assen, the Netherlands: Van Gorcum.

United Nations Development Program [UNDP]. (1994). Sustainable buman development and agriculture. New York: Author.

UNDP. (2007). Global environment outlook 4 (GEO-4): Environment for development. Malta: Progress Press.

Wasi, P. (1988). Buddhist agriculture and the tranquility of Thai society. In S. Phongphit \& R. Bennoun (Eds.), Turning point of Thai farmers (pp. 1-43). Bangkok: Thai Institute for Rural Development.

White, P. T. (1994). Rice: The essential harvest. National Geographic, 185(5), 48-79.

Willer, H., \& Yussefi, M. (Eds.). (2004). The world of organic agriculture 2004: Statistics and emerging trends. Bonn: IFOAM. Retrieved from http://www.organic-world.net/yearbook/formereditions.html?L $=0$

World Health Organization. (1946). Constitution of the World Health Organization. Geneva: Author. Retrieved from http://www.who.int/library/ collections/historical/en/index3.html

Wyatt, D. K. (1982). Thailand: A short history. Bangkok: Silkworm Books. 